\title{
Effect of LED Lighting during Incubation of Fayoumi Eggs on Hatchability and Chick Performance
}

\author{
Karim EL-SABROUT 's \\ ${ }^{1}$ Department of Poultry Production, Faculty of Agriculture (El-Shatby), University of Alexandria, Alexandria, EGYPT \\ Article Code: KVFD-2017-18025 Received: 12.05.2017 Accepted: 16.07.2017 Published Online: 16.07.2017 \\ Citation of This Article \\ El-Sabrout K: Effect of LED lighting during incubation of fayoumi eggs on hatchability and chick performance. Kafkas Univ Vet Fak Derg, 23 (6): \\ 1007-1009, 2017. DOI: 10.9775/kvfd.2017.18025

\begin{abstract}
This study aims to evaluate the effect of LED lighting during incubation of Fayoumi eggs on hatchability and hatch chick performance. The experiment was carried out in three groups with total number of 2100 eggs. Eggs were incubated $24 \mathrm{~h}$ of complete darkness (G1); $24 \mathrm{~h}$ of complete LED lighting (G2); and $12 \mathrm{~h}$ of LED lighting then $12 \mathrm{~h}$ of darkness (G3). From the obtained results, there were no effects of LED lighting on hatchability percent and dead embryos. There were significant differences observed in chick performance among the three groups, chick weight at hatch was the heaviest in group of eggs exposed to complete LED lighting during incubation (G2) with high vitality percent.
\end{abstract}

Keywords: Chicken's eggs, LED lighting, Hatchability, Chick performance

\section{Fayoumi Yumurtalarda İnkubasyon Süresince LED Işıklandırmanın Yumurtadan Çıkma ve Civciv Performansına Etkisi}

\begin{abstract}
Özet
Bu çalışmanın amacı Fayoumi yumurtalarda inkubasyon süresince LED ıșıklandırmanın yumurtadan çıkma ve civciv performansı üzerine etkisini araştırmaktır. Toplam 2100 yumurta kullanılarak ve üç grup olacak şekilde çalışma yürütüldü. Yumurtalar 24 saat tümüyle karanlık (G1), 24 saat tümüyle LED ışıklandırma (G2) ve 12 saat LED ışıklandırma ve sonrasında 12 saat karanlık (G3) olacak şekilde inkube edildiler. Sonuçlar LED ışıklandırmanın yumurtadan çıkma yüzdesi ve embriyo ölümlerine etkisinin olmadığını gösterdi. Her üç grup arasında civciv performansında anlamlı bir fark gözlenmedi. Yumurtadan çıkma zamanında civciv ağırığı inkubasyon sırasında tümüyle LED ışığa maruz kalanlarda (G2) en fazla olup yüksek hayatta kalma yüzdesine sahipti.
\end{abstract}

Anahtar sözcükler: Tavuk yumurtası, LED ışıklandırma, Yumurtadan çıkma, Civciv performansı

\section{INTRODUCTION}

To meet the high demand on poultry products, producers are adopting new technologies that will enable them to increase production at a reduced cost. Most of these production technologies focus on enhancing the environmental conditions surrounding the avian population. These environmental conditions are critical elements during embryogenesis of avian well-being. By using light-emitting diode (LED), breeders can increase production and reduce mortality with lower energy consumption and longer life use than fluorescent or conventional incandescent lighting ${ }^{[1]}$.

Fayoumi chickens have a good hatchability percent as a local strain ${ }^{[2]}$. Generally, chicken's eggs are often incubated commercially in semi or complete darkness, but under natural conditions, avian embryos would certainly receive some light stimulation during development ${ }^{[3]}$. Avian embryos have a pineal gland sensitive for light that affects their growth ${ }^{[4]}$. During incubation, exposing eggs to light can increase the embryo's growth ${ }^{[5]}$ and decrease time of incubation ${ }^{[6]}$. However, numerous studies have shown the importance of exposing embryos to light $[7,8]$, but few of them ${ }^{[9]}$ have shown the LED lighting effects on hatchability and chick performance. Huth and Archer ${ }^{[9]}$ indicated that providing LED light during incubation can improve chick quality.

Therefore, the current study was conducted to investigate the effect of complete/complement LED lighting during

\section{8 iletişim (Correspondence) \\ 篗 +201008984822}


chicken's eggs incubation on hatchability and hatch chick performance.

\section{MATERIAL and METHODS}

A total number of 2100 Fayoumi chicken (Gallus Gallus domesticus) eggs were randomly distributed into three groups (700 eggs for each group and each one was further divided into 7 replicates) and incubated in a commercial hatchery under the recommended conditions $\left(37.5^{\circ} \mathrm{C}\right.$ and $60 \% \mathrm{RH}$ ) with/without LED lighting as follows: the first group (control) was incubated $24 \mathrm{~h}$ of complete darkness (G1); while the second group was incubated $24 \mathrm{~h}$ of complete LED lighting (yellow, 6 Watt, 540 Leumans) (G2); and the third group was incubated $12 \mathrm{~h}$ of LED lighting (yellow, 6 Watt, 540 Leumans) then 12 h of darkness (G3). The study was approved by Alexandria University Animal Ethics Committee (2016-2/18). All chicks were removed at 21-day of incubation.

Data of hatchability percent, embryo mortality [at $7^{\text {th }}$ (early dead) and $18^{\text {th }}$ (late dead) day of incubation] and chick performance (weight, vitality) at hatch were recorded. All the hatched chicks were weighted and examined in order to determine their vitality which included their activity, appearance, eyes, walking, wing flapping, unhealed navel and weakness to stand. The chick vitality levels were using a scale from 1 (poor quality) to 5 (high quality) according to Farghly et al. ${ }^{[10]}$.

One-way ANOVA was used to investigate treatment effects on hatchability and hatch chick performance by SPSS statistical software ${ }^{[11]}$. Duncan's multiple range test was used to detect differences among means of the three groups.

\section{RESULTS}

The effect of LED lighting during eggs incubation on hatchability and chick performance was presented in Table 1. There was no significant effect $(P<0.05)$ on hatchability percent of eggs. Also, there was no significant effect
$(P<0.05)$ of LED lighting on early and late dead embryos. Differences were observed among groups in incubation period, eggs of $G 2(L E D)$ had the lowest $(P<0.05)$ incubation time (hours). Also, there was a difference observed in chick performance among the three groups, chick weight at hatch was the heaviest in group of eggs exposed to complete LED lighting (G2) with high vitality level.

\section{DISCUSSION}

To reach high economical efficiency in hatchability, optimal incubation conditions must be providing. Light is one of these conditions that improves embryonic growth and hatchability performance of avian eggs ${ }^{[7]}$. Also, the type and amount of light could affect hatchability and chick performance ${ }^{[5]}$. LED lighting provides an approximation of daylight than the spectral gaps of other lightings. Therefore, we used LED lamps in this study by exposing the Fayoumi eggs to complete/complement LED lighting during the incubation to test its impact. In agreement with previous study of Archer et al. ${ }^{[8]}$, there was no effect of complete/complement LED lighting on hatchability percent of eggs (Table 1). Also, we observed that early and late dead embryos were not change among groups. This result corresponds to findings by Huth and Archer ${ }^{[9]}$. The eggs exposed to complete/complement LED lighting were hatched before the control eggs; thereby, increasing productivity. It means that LED lighting affect the incubation period. It can also affect the hatch window of eggs. The earliness in the hatching time due to light providing may can be refer to accelerate embryonic development rate ${ }^{[12]}$. Eggs exposed to complete LED light (G2) showed an increase in hatch chick weight compared to G1 and G3 eggs. Light regime helps to increase the embryonic plasma T3 levels which have a positive correlation with metabolic rate and development of chicken embryos ${ }^{[13]}$. Moreover, lighting treatment regulated melatonin production at post hatch period, which in turn affects some physiological functions of chicks ${ }^{[14]}$. However, this result is in agreement with Farghly and Mahrose ${ }^{[15]}$ who reported that the eggs incubated under continuous lighting produced heavier

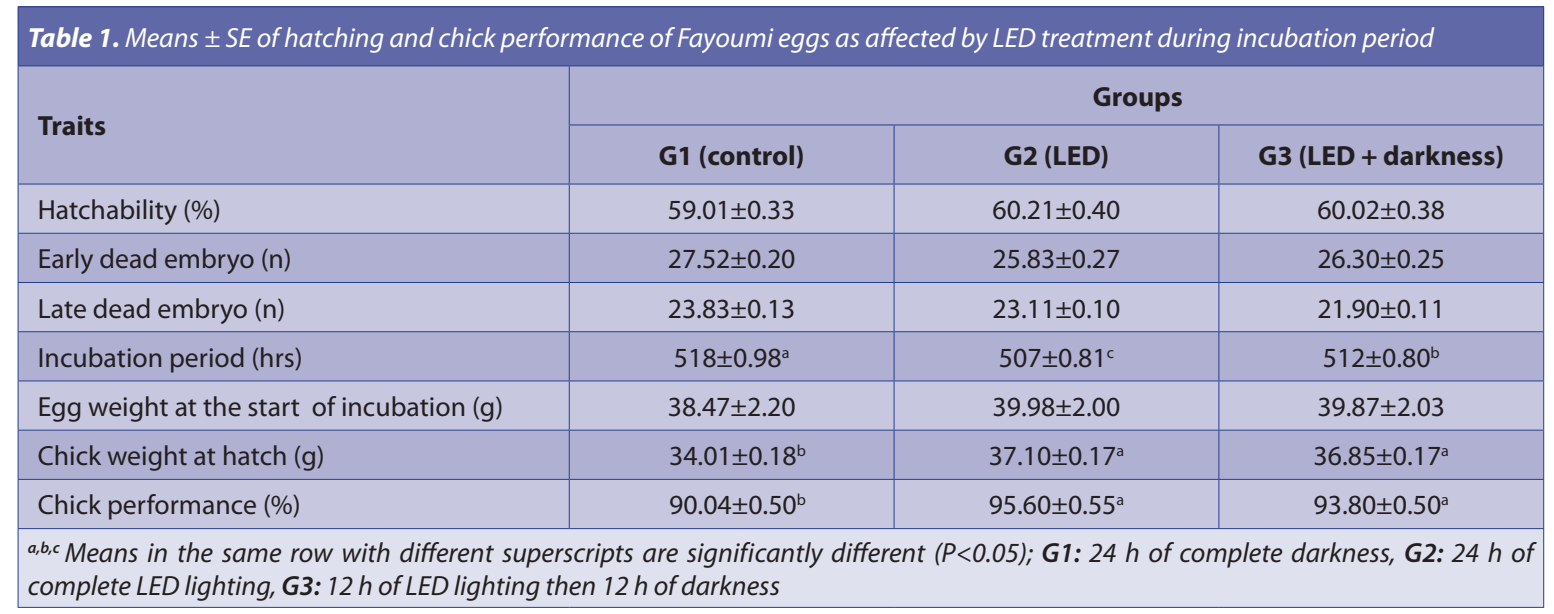


chicks than those incubated in the dark. With similar trend, Farghly et al. ${ }^{[10]}$ reported that the highest value of embryo weight was observed under incubated light flashes.

Furthermore, the G2 chicks showed high vitality level than G1 and G3. These results indicate that providing LED light during incubation can improve hatch chick performance. This result is in accordance with that observed by Khalil ${ }^{16]}$, who revealed that chicks hatched under light regime incubation appeared to be more active when compared with those hatched under dark incubation. Huth and Archer ${ }^{[9]}$ indicated that providing LED light during incubation can improve chick quality. These improvements mainly related to the physiological and metabolic responses to light during embryonic development.

According to the results obtained in this study, there is no statistical difference between the groups in terms of hatchability, early dead embryo and late dead embryo. There is a significant association between the providing of LED lighting during chicken eggs incubation and the hatch chick performance. Light induced from the LED lamps during incubation improved chick's performance. Data of G2 and G3 were closely, therefore, it recommends that complete or complement LED lighting could be applied during eggs incubation to have high hatch chick's performance. Further studies with more details especially on chick behavior and physiology are needed to provide obvious explanation.

\section{ACKnOWledgement}

The author would like to thank Eng. Mohamed Abdel Rahman - director of Abdel Rahman incubators - for his kind assistance with this work.

\section{REFERENCES}

1. Gongruttananun N: Influence of red light on reproductive performance eggshell ultrastructure, and eye morphology in Thai-native hens. Poult Sci, 90, 2855-2863, 2011. DOI: 10.3382/ps.2011-01652

2. Khalil MH, Shebl MK, Kosba MA, El-Sabrout K, Zaki N: Estimate the contribution of incubation parameters influence egg hatchability using multiple linear regression analysis. Vet World, 9, 806-810, 2016. DOI: 10.14202/vetworld.2016.806-810

3. Rogers LJ: The development of brain and behaviour in the Chicken. CABI Publishing, Wallingford, UK, 1996.

4. Zeman M, Gwinner E, Somogyiova E: Development of melatonin rhythm in the pineal-gland and eyes of chick-embryo. Experientia, 48, 765-768, 1992.

5. Shafey TM: Effect of lighted incubation on embryonic growth and hatchability performance of two strains of layer breeder eggs. Br Poult Sci, 45, 223-229, 2004. DOI: 10.1080/00071660410001715821

6. Fairchild BD, Christensen VL: Photostimulation of turkey eggs accelerates hatching times without affecting hatchability, liver or heart growth, or glycogen content. Poult Sci, 79, 1627-1631, 2000. DOI: 10.1093/ ps/79.11.1627

7. Shafey TM, AI-Mohsen TH: Embryonic growth, hatching time and hatchability performance of meat breeder eggs incubated under continuous green light. Asian-Australas J Anim Sci, 15, 1702-1707, 2002. DOI: 10.5713/ajas.2002.1702

8. Archer GS, Shivaprasad HL, Mench JA: Effect of providing light during incubation on the health, productivity, and behavior of broiler chickens. Poult Sci, 88, 29-37, 2009. DOI: 10.3382/ps.2008-00221

9. Huth JC, Archer GS: Effects of LED lighting during incubation on layer and broiler hatchability, chick quality, stress susceptibility and post-hatch growth. Poult Sci, 94, 3052-3058, 2015. DOI: 10.3382/ps/pev298

10. Farghly MF, Mahrose KhM, Abou-kassem DE: Pre and post hatch performance of different Japanese quail egg colors incubated under photostimulation. Asian J Poult Sci, 9, 19-30, 2015. DOI: 10.3923/ajpsaj. 2015.19.30

11. SPSS: Statistical Package for the Social Sciences. SPSS User's Guide: Statistics, Version 20.0 for Windows, Institute, Inc., Cary, NC, USA, 2011.

12. Ghatpande A, Ghatpande S, Khan MZ: Effect of different intensities of fluorescent light on the early development of chick embryos in ovo. Cell Mol Bio Res, 41, 613-621, 1995.

13. Lu JW, Mcmurtry JP, Coon CN: Developmental changes of plasma insulin, glucagon, insulin-like growth factors, thyroid hormones, and glucose concentrations in chick embryos and hatched chicks. Poult Sci, 86, 673-683, 2007. DOI: 10.1093/ps/86.4.673

14. Nelson RJ, Demas GE: Role of melatonin in mediating seasonal energetic and immunologic adaptations. Brain Res Bull, 44, 423-430, 1997. DOI: 10.1016/S0361-9230(97)00222-0

15. Farghly MF, Mahrose KhM: Effect of light during storage and incubation periods on pre and post hatch performance of Japanese quail. Egypt J Poult Sci, 32, 947-958, 2012.

16. Khalil HA: Productive and physiological responses of Japanese quail embryos to light regime during incubation period. Slovak J Anim Sci, $42,79-86,2009$ 